\title{
Omega-3 intake in people with epilepsy under regular hemodialysis program: here to stay
}

\author{
Suplementação de ômega 3 em pessoas com epilepsia \\ submetidas a um programa regular de hemidiálise: veio para ficar
}

Carla Alessandra Scorza', Ricardo Mario Arida², Roberta Monterazzo Cysneiros ${ }^{3}$, Esper Abrão Cavalheiro', Fulvio Alexandre Scorza ${ }^{1}$

\begin{abstract}
Among the many risk factors suggested for sudden unexpected death in epilepsy (SUDEP), higher frequency of seizures is a very consistent issue. Furthermore, it has been established that hemodialysis-associated seizure is a complication of the dialysis procedure. Thus, since a possible relation between cardiovascular abnormalities and SUDEP among patients with chronic renal insufficiency in regular hemodialysis program should not be neglected, we propose in this paper that omega-3 fatty acids offer opportunities for prevention of sudden cardiac death or improved treatment in people with epilepsy under the regular hemodialysis program.
\end{abstract}

Key words: epilepsy, death, sudden, omega 3, hemodialysis.

\section{RESUMO}

Dentre os fatores de risco sugeridos para a morte súbita inesperada em epilepsia (SUDEP), maior frequência de crises epilépticas é uma questão muito consistente. Além disso, tem sido estabelecido que as crises epilépticas associadas à hemodiálise são uma complicação do procedimento dialítico. Desse modo, como a existência de uma possível associação entre as alterações cardiovasculares e a SUDEP entre indivíduos com insuficiência renal crônica em tratamento dialítico não deve ser negligenciada, foi proposto neste artigo que o ômega 3 pode atuar na prevenção da morte súbita cardíaca ou melhorar o tratamento de pessoas com epilepsia inseridas em um programa regular de hemodiálise.

Palavras-Chave: epilepsia, morte súbita, ômega-3, hemodiálise.

The development of new treatments and effective strategies to prevent or reverse chronic human diseases must be the main goal of national health systems. This is easily established when the organization effectively translates findings in biomedical research into clinical practice and uses them on decision-makings in health policies. Translational medicine is the basis of this progress. This is a continued process that involves the direct application of discoveries from the bench to the development of studies in humans. It places together all results from these studies and applies them to clinical practice, in an attempt to improve health conditions and quality of life of the population. It may also facilitate the adoption of best medical practices by the community.
In practice, this interdisciplinary approach works well in several fields ${ }^{1}$, however it is still unusual among nephrologists and neurologists. In Nephrology, it is generally accepted that chronic renal failure is a worldwide public health problem. People with this condition undergo dialysis treatment, may require kidney transplant and have an increased risk of cardiovascular disease and hence sudden death ${ }^{2}$. In Neurology, the story is quite similar. Epilepsy is one of the most prevalent neurological diseases worldwide and mortality rates are considerably higher in those that bear it ${ }^{3-6}$.

Sudden unexpected death in epilepsy (SUDEP) is the main cause of death in people with chronic epilepsy ${ }^{3-6}$, accounting for $17.0 \%$ of them. It has an incidence among epileptic adults between 1:500 and 1:1,000 patient-years ${ }^{7}$. A single

\footnotetext{
${ }^{1}$ Disciplina de Neurologia Experimental, Escola Paulista de Medicina, Universidade Federal de São Paulo (EPM/Unifesp), São Paulo SP, Brazil; ${ }^{2}$ Departamento de Fisiologia, EPM/Unifesp, São Paulo SP, Brazil;

${ }^{3}$ Programa de Pós-Graduação em Distúrbios do Desenvolvimento do Centro de Ciências Biológicas e da Saúde, Universidade Presbiteriana Mackenzie, São Paulo SP, Brazil.

Correspondence: Fulvio Alexandre Scorza; Rua Botucatu 862 / Edifício Leal Prado; 04023-900 São Paulo SP - Brasil; E-mail: scorza.nexp@epm.br Support: Grants from Fundação de Amparo à Pesquisa do Estado de São Paulo (Fapesp); Conselho Nacional de Desenvolvimento Científico e Tecnológico (CNPq); FAPEMIG; PRONEX and Instituto Nacional de Neurociência Translacional (MCT).

Conflict of interest: There is no conflict of interest to declare.

Received 26 November 2012; Received in final form 01 March 2013; Accepted 08 March 2013.
} 
mechanism is not established for SUDEP, but evidences suggest that the major domain is cardiovascular dysregulation during and after seizures ${ }^{8-12}$. As these two chronic diseases are very common and have high rates of sudden death, we evaluated what would be the scenario if the same person had both conditions ${ }^{13}$. In order to do it, we investigated the relationship of seizure frequencies in people with end-stage renal disease (ESRD) under regular dialysis program ${ }^{14}$. Seven out of 189 ESRD cases had convulsive seizure during the dialytic program $^{14}$, therefore it was evident that despite the belief that seizures were rare among ESRD individuals receiving dialysis, this was not the case. Indeed, this suggested that a clinical convergence of neurologists and nephrologists in the context would be helpful ${ }^{13-15}$.

We also looked at a possible link between epilepsy, cardiovascular abnormalities, and SUDEP among ESRD cases undergoing regular hemodialysis ${ }^{13,16}$. It was found that abnormalities of cardiac rhythm and SUDEP are unusual events in this specific population ( 7 out of 209$)^{13,16}$. This data has to be cautiously interpreted as the numbers examined are small, but our conclusion is that the flame of translational science among health professionals directly involved with these people must be permanently lit. For these new considerations, experimental, epidemiological, and clinical studies should be carried out to establish the association between epilepsy, cardiovascular abnormalities, and sudden death in people on dialysis ${ }^{13,17}$.

Currently, the ultimate goal in neurology and nephrology research in regards to cardiovascular changes that may lead to sudden death is to develop new methods to prevent it and to establish actions other than medical that may be effective. Therapy or supplementation with a 'natural' substance has shown interesting and promising benefits in this regard: the omega-3 fatty acids (omega-3 FAs). A number of experimental and clinical studies could be put forward to demonstrate the effectiveness of omega-3 FAs in epilepsy and dialysis fields.

In epilepsy, despite the need to perform clinical trials with higher doses and longer periods of omega-3 FAs to definitively assess their anti-seizure effects, it is already well-established that their supplementation reduces the convulsion frequency, promotes neuroprotection and positive neuroplastic changes in animal models and in some people with uncontrolled epilepsy ${ }^{18-23}$. Omega-3 FAs per se is able to improve vascular and cardiac hemodynamics, triglycerides, autonomic control, inflammation, thrombosis, arrhythmia and to reduce the risk of cardiac death, which may have implications for SUDEP prevention ${ }^{24,25}$.

It has been postulated that omega-3 FAs supplementation in people with refractory epilepsy may not only reduce seizures but also their cardiac arrhythmias and hence SUDEP $^{26}$. In these lines, a pilot, randomized, double-blind two-period crossover clinical trial of high-dose omega-3 FAs in 11 subjects with refractory seizures was carried out ${ }^{27}$. This was the first trial to demonstrate the beneficial effects of omega-3 FAs on cardiac risk factors and heart rate variability in people with epilepsy. It provided evidence that fish oil may reduce the risk of SUDEP in epilepsy ${ }^{27}$, which was also confirmed experimentally ${ }^{28-30}$.

In dialysis, omega-3 FAs have been clinically and experimentally assessed due to their proven benefits in advanced chronic kidney disease (CKD), such as renoprotection in IgA nephropathy, cardioprotection via a variety of mechanisms including triglyceride levels and blood pressure reduction, maintenance of dialysis access patency, sparing of inflammation-associated muscle loss, and reduced mortality ${ }^{17,31,32}$. In these lines, we fully agree with this and have recently confirmed it in a trial (Rui Alberto Gomes, PhD Thesis - unpublished data). Briefly, we evaluated the omega-3 FAs effects on individuals under hemodialysis treatment with low quality of life and high mortality risk. Patients received daily supplementation of $2 \mathrm{~g}$ omega-3 FAs in oral capsules, for three months, in a six-month period. Biochemical analysis was carried out at three points, generating three groups of variables (before, during, and after omega-3 FAs supplementation). A reduction of inflammatory markers, with significant reduction of white blood cells in peripheral blood, in the glycemic, $\mathrm{C}$-reactive protein and triglyceride levels, was seen. There was also a quality of life (QoL) score improvement on the SF-36 instrument, especially in the physical health dimension (Rui Alberto Gomes, PhD Thesis - unpublished data).

Given the importance of these results, the 2005 Kidney Disease Outcomes Quality Initiative Clinical Practice Guidelines specifically encourage further research on the effects of kidney failure and/or dialysis on omega-3 FAs metabolism and blood/tissue levels. It also calls the attention for clinical trials designed to evaluate the effects of omega-3 FAs supplementation on cardiovascular risk and outcomes ${ }^{17,31-33}$. It is important to note that sudden cardiac death is the most common cause of death in ESRD individuals under regular dialysis program usually caused by ventricular arrhythmias, such as ventricular tachycardia and fibrillation ${ }^{34}$. Therefore, omega-3 FAs supplementation can be of value in a preventive strategy for cardiovascular abnormalities in individuals undergoing dialysis. This is due to its antiarrhythmic properties as well to its well-established ability to reduce the risk of cardiac death ${ }^{35}$.

The scientific field exploring omega-3 FAs is innovative, evolving, and promising. It needs, however, to be remembered that humans cannot synthesize omega-3 FAs. Thus, it must be obtained from the $\operatorname{diet}^{36}$. The only aliments that provide large amounts of omega-3 with low levels of contaminants (i.e., methylmercury) are oily sea fish as anchovies, herring, mackerel, salmon, sardines, and trouts ${ }^{37,38}$. Guidelines have converged on consistent recommendations for the general population to consume at least $250 \mathrm{mg}$ /day of long-chain omega-3 FAs or at least two weekly servings of oily fish ${ }^{35}$. On that basis, fish is one of the most important 
foodstuffs we can choose for cardiovascular and brain health. For individuals who do not tolerate fish or want a diet with no contaminants but at the same time are keen to enjoy the benefits of omega-3 FAs, options include fish oil supplements or the intake of some food, such as walnuts or oils (flax, canola, and soybean) $)^{39,40}$.

While we are unable to prevent ESRD and epilepsy or to reverse the clinical scenario when they are installed, the use of omega-3 FAs could be an option to prevent cardiovascular abnormalities and hence sudden cardiac death in these patients. There is still the need to confirm the utility, and to establish intake recommendations and optimal dosing of omega-3 $\mathrm{FAs}^{32}$, however it is more than time to institute a task force to assess the state of knowledge (clinical management, research directions, and educational, social, and cultural efforts) in order to put into practice these strategies.

Finally, these creative efforts about omega-3 FAs offer opportunities for preventing sudden cardiac death or improved treatment in people with epilepsy under regular hemodialysis program. With this proposal, we should not forget the famous words of philosopher Socrates: "We do not live to eat but eat to live".

\section{ACKNOWLEDGEMENTS}

The authors acknowledge the many valuable suggestions made by Ley Sander, Professor of Neurology and Clinical Epilepsy of the UCL Institute of Neurology, and Honorary Consultant Neurologist at the National Hospital for Neurology and Neurosurgery, Queen Square, London, in the United Kingdom. We are also indebted to doctor Rui Alberto Gomes and his entire multidisciplinary team from the Institute of Nephrology of Mogi das Cruzes, São Paulo, in Brazil, for his help, assistance, and research development.

\section{References}

1. Goldblatt EM, Lee WH. From bench to bedside: the growing use of translational research in cancer medicine. Am J Transl Res 2010;2:01-18.

2. Herzog CA, Mangrum JM, Passman R. Sudden cardiac death and dialysis patients. Semin Dial 2008;21:300-307.

3. Scorza FA. Epilepsy kills. Arq Neuropsiquiatr 2012;70:226-227.

4. Nashef L, Ryvlin P. Sudden unexpected death in epilepsy (SUDEP): update and reflections. Neurol Clin 2009;27:1063-1074.

5. Duncan JS, Sander JW, Sisodiya SM, Walker MC. Adult epilepsy. Lancet 2006;367:1087-1100

6. Nei M, Hays R. Sudden unexpected death in epilepsy. Curr Neurol Neurosci Rep 2010;10:319-326.

7. Schuele SU, Widdess-Walsh P, Bermeo A, Lüders HO. Sudden unexplained death in epilepsy: the role of the heart. Cleve Clin J Med 2007;74:S121-S127.

8. Surges R, Sander JW. Sudden unexpected death in epilepsy: mechanisms, prevalence, and prevention. Curr Opin Neurol 2012;25:201-207.

9. Hesdorffer DC, Tomson T, Benn E, et al. Combined analysis of risk factors for SUDEP. Epilepsia 2011;52:1150-1159.

10. Surges R, Thijs RD, Tan HL, Sander JW. Sudden unexpected death in epilepsy: risk factors and potential pathomechanisms. Nat Rev Neurol 2009;5:492-504.

11. Tomson T, Nashef L, Ryvlin P.Sudden unexpected death in epilepsy: current knowledge and future directions. Lancet Neurol 2008;7:1021-1031.

12. Stollberger C, Finsterer J. Cardiorespiratory findings in sudden unexplained/unexpected death in epilepsy (SUDEP). Epilepsy Res 2004;59:51-60

13. Scorza FA, Arida RM, Terra VC, Gomes RA, Cavalheiro EA. People with epilepsy receiving renal replacement therapy with hemodialysis: Scientists recall progress and promise of translational research. Arq Neuropsiquiatr 2011;69:143-144.

14. Scorza FA, Albuquerque M, Arida RM, et al. Seizure occurrence in patients with chronic renal insufficiency in regular hemodialysis program. Arq Neuropsiquiatr 2005;63:757-760.

15. Scorza FA, Arida RM, Cavalheiro EA. Cardiovascular abnormalities in patients with epilepsy receiving renal replacement therapy with dialysis: a true convergence of clinical cardiology, nephrology and neurology. Nephrol Dial Transplant 2008;23:1775-1776

16. Gomes RA, Kesrouani S, Cruz J, et al. Is there something special about cardiovascular abnormalities and sudden unexpected death in epilepsy among patients with chronic renal insufficiency in regular hemodialysis program? Arq Neuropsiquiatr 2009;67:209-213.

17. Scorza FA, Scattolini M, Cysneiros RM, et al. Sudden unexpected death in patients with epilepsy receiving renal replacement therapy with dialysis: a 17-year experience at a single institution. Hemodial Int 2010;14:364-369.

18. Taha AY, Burnham WM, Auvin S. Polyunsaturated fatty acids and epilepsy. Epilepsia 2010;51:1348-1358.

19. Ferrari D, Cysneiros RM, Scorza CA, et al. Neuroprotective activity of omega-3 fatty acids against epilepsy-induced hippocampal damage: quantification with immunohistochemical for calcium-binding proteins. Epilepsy Behav 2008;13:36-42.

20. Cysneiros RM, Ferrari D, Arida RM, et al. Qualitative analysis of hippocampal plastic changes in rats with epilepsy supplemented with oral omega-3 fatty acids. Epilepsy Behav 2010;17:33-38.

21. Schlanger S, Shinitzky M, Yam D. Diet enriched with omega-3 fatty acids alleviates convulsion symptoms in epilepsy patients. Epilepsia 2002:43:103-104

22. Yuen AW, Sander JW, Fluegel D, et al. Omega-3 fatty acid supplementation in patients with chronic epilepsy: a randomized trial. Epilepsy Behav 2005;7:253-258.

23. Yuen AW, Flugel D, Poepel A, Bell GS, Peacock JL, Sander JW. Nonrandomized open trial of eicosapentaenoic acid (EPA), an omega-3 fatty acid, in ten people with chronic epilepsy. Epilepsy Behav 2012;23:370-372.

24. Calder PC. n-3 Fatty acids and cardiovascular disease: evidence explained and mechanisms explored. Clin Sci 2004;107:01-11.

25. Mozaffarian D, Wu JH. Omega-3 fatty acids and cardiovascular disease: effects on risk factors, molecular pathways, and clinical events. J Am Coll Cardiol 2011;58:2047-2067.

26. Yuen AW, Sander JW. Is omega-3 fatty acid deficiency a factor contributing to refractory seizures and SUDEP? A hypothesis. Seizure 2004;13:104-107. 
27. DeGiorgio CM, Miller P, Meymandi S, Gornbein JA. n-3 Fatty acids (fish oil) for epilepsy, cardiac risk factors, and risk of SUDEP: clues from a pilot, double-blind, exploratory study. Epilepsy Behav 2008;13:681-684.

28. Scorza FA, Cysneiros RM, Arida RM, Terra-Bustamante VC, de Albuquerque M, Cavalheiro EA. The other side of the coin: beneficiary effect of omega-3 fatty acids in sudden unexpected death in epilepsy. Epilepsy Behav 2008;13:279-283.

29. Scorza FA, Arida RM, Terra VC, Cavalheiro EA. What can be done to reduce the risk of SUDEP? Epilepsy Behav 2010;18:137-138.

30. Colugnati DB, Gomes PA, Arida RM, et al. Analysis of cardiac parameters in animals with epilepsy: possible cause of sudden death? Arq Neuropsiquiatr 2005;63:1035-1041.

31. Friedman A, Moe S. Review of the effects of omega-3 supplementation in dialysis patients. Clin J Am Soc Nephrol 2006;1:182-192.

32. Friedman AN. Omega-3 fatty acid supplementation in advanced kidney disease. Semin Dial 2010;23:396-400.

33. K/DOQIWorkgroup.K/DOQI clinical practice guidelines for cardiovascular disease in dialysis patients. Am J Kidney Dis 2005;45:S91-S95.
34. Passman R, Herzog CA. End-stage renal disease: sudden cardiac death: stratifying risk in dialysis patients. Nat Rev Nephrol 2011;7:133-135.

35. Mozaffarian D, Wu JH. Omega-3 fatty acids and cardiovascular disease: effects on risk factors, molecular pathways, and clinical events. J Am Coll Cardiol 2011;58:2047-2067.

36. Bourre JM. Omega-3 fatty acids in psychiatry. Med Sci 2005;21:216-221.

37. Smith KM, Sahyoun NR. Fish consumption: recommendations versus advisories, can they be reconciled? Nutr Rev 2005;63:39-46.

38. No authors listed. Fish: friend or foe? In addition to heart-healthy omega-3 fats, seafood can carry mercury and other toxins. For most people, the benefits of eating fish far outweigh the risks. Harv Heart Lett 2007;17:4-6.

39. Jeejeebhoy KN. Benefits and risks of a fish diet--should we be eating more or less? Nat Clin Pract Gastroenterol Hepatol 2008;5:178-179.

40. Domingo JL. Omega-3 fatty acids and the benefits of fish consumption: is all that glitters gold? Environ Int 2007;33:993-998. 